Acta vet. scand. $1977,18,522-531$.

From the Department of Pathology, Veterinary College of Norway, Oslo.

\title{
THE SEQUENCE OF EVENTS \\ IN THE DEVELOPMENT OF BILATERAL RENAL CORTICAL NECROSIS ACCOMPANYING THE GENERALIZED SHWARTZMAN REACTION
}

\author{
By \\ Knut Nordstoga
}

\begin{abstract}
NORDSTOGA, KNUT: The sequence of events in the development of bilateral renal cortical necrosis accompanying the generalized Shwartzman reaction. Acta vet. scand. 1977, 18, 522-531. - The generalized Shwartzman reaction, or Shwartzman-like conditions, were induced in a variety of experimental mammalian species by systemic injections of disintegrated cells of Gram negative bacteria, live Salmonella cholerae-suis or Liquoid. A comparative study of the renal lesions showed that the initial step in the development of bilateral cortical necrosis is stagnation and disintegration of red cells in glomerular capillaries. The glomerular "microthrombi" consist mainly of erythrocytic debris, which frequently has staining properties akin to those of fibrin; even wide-spread glomerular "thrombosis" is not accompanied by obvious destruction of renal parenchyma. A second step is necrotic mural lesions in afferent arteries, with ensuing thrombosis. These vascular lesions lead to the formation of individual infarcts which fuse to form total bilateral cortical necrosis in fulminant cases of the generalized Shwartzman reaction.
\end{abstract}

bilateral cortical necrosis; renal infarcts; erythrocytes; microthrombosis; thrombosis; generalized Shwartzman reaction.

The first description of bilateral renal cortical necrosis (BCN) was given in man by Friedländer (1883). This peculiar renal lesion seems, however, to have received relatively little attention until BCN was associated with the experimental generalized Shwartzman reaction (GSR) many years later. At present most workers seem to interpret $\mathrm{BCN}$ as a morphological criterion of the GSR, a condition which is best known from experiments in rabbits, and is most commonly induced by intravenous injections of bacterial endotoxins (Thomas \& Good 1952, McKay 1965). 
During recent years we have performed a series of experiments in order to study the patho-morphological lesions in GSR, and GSR-like conditions. For comparative studies, we have used a number of experimental animal species and somewhat varying techniques (Nordstoga \& Fjølstad 1967, 1970, 1973, 1975, Nordstoga 1974, 1977). This paper briefly summarizes our investigations, and presents what we feel, retrospectively, are the most essential patho-morphological features, and the succession in which they occur, during the development of the fulminant renal Shwartzman lesion, viz. symmetrical necrosis of the cortex.

\section{MATERIAL AND METHODS}

This communication comprises kidney material from experimental animals in which the GSR, or GSR-like conditions, were produced by intravenous, or intracardial injections of disintegrated cells of various Gram negative bacteria (Haemophilus parainfluenzae, Salmonella cholerae-suis, and a haemolytic strain of Escherichia coli). Animals belonging to 9 different mammalian species were used. In addition, kidneys from pigs injected with live S. cholerae-suis were studied, and finally, specimens from animals of 5 different species injected with $\mathrm{Li}$ quoid. Details of the experimental procedures are given in previous papers (Nordstoga \& Fjølstad 1967, 1970, 1973, 1975, Nordstoga 1974, 1977).

\section{RESULTS}

Gross renal involvement in species which developed obvious renal changes is listed in Table 1 .

\section{Light microscopic findings}

Microscopically, it was found that the isolated necrotic cortical lesions corresponded to classical infarcts (Fig. 1), and that evident macroscopic necrotic lesions were always accompanied by necrotic changes in arterial walls, most pronounced in interlobular arteries and in afferent glomerular arterioles, the mural injury frequently extending to necrotizing arteritis (Figs. 2-5). "Microthrombosis" of glomerular capillaries was, as a rule, also present in these cases. On the other hand, glomerular capillary "thrombosis" was frequently present in the absence of obvious necrotic alterations in renal parenchyma. This was most clearly 
T a b le 1. Treatment, animal species and maximal renal involvement.

\begin{tabular}{|c|c|c|}
\hline Method & Species & Renal changes \\
\hline \multirow{5}{*}{$\begin{array}{l}\text { Systemic injections of } \\
\text { crushed cells of Gram } \\
\text { negative bacteria }\end{array}$} & $\begin{array}{l}\text { pigs } \\
\text { (Sus scrofa) }\end{array}$ & $\mathrm{BCN}$ \\
\hline & $\begin{array}{l}\text { rabbits } \\
\text { (Oryctolagus cuniculus) }\end{array}$ & BCN \\
\hline & $\begin{array}{l}\text { ferrets } \\
\text { (Mustela putorius furo) }\end{array}$ & $\begin{array}{l}\text { multiple } \\
\text { infarcts }\end{array}$ \\
\hline & $\begin{array}{l}\operatorname{mink} \\
\text { (Mustela vison) }\end{array}$ &,-- \\
\hline & $\begin{array}{l}\text { blue foxes } \\
\text { (Alopex lagopus) }\end{array}$ & $\begin{array}{l}\text { scattered cortical } \\
\text { haemorrhages }\end{array}$ \\
\hline $\begin{array}{l}\text { Intravenous } \\
\text { inoculation } \\
\text { of live } \\
\text { S. cholerae- } \\
\text { suis }\end{array}$ & pigs & $\begin{array}{l}\text { haemorrhagic } \\
\text { cortical tissue }\end{array}$ \\
\hline \multirow{3}{*}{$\begin{array}{l}\text { Intravenous } \\
\text { injections } \\
\text { of Liquoid }\end{array}$} & pigs & multiple infarcts \\
\hline & rabbits & $\mathrm{BCN}$ \\
\hline & blue foxes & $\begin{array}{l}\text { uneven colour of } \\
\text { external surfaces }\end{array}$ \\
\hline
\end{tabular}

demonstrated in the early stage of porcine salmonellosis, and in blue foxes injected intravenously with Liquoid (Fig. 6).

\section{Electron microscopic findings}

Electron microscopic examinations of kidney material of mink injected with disintegrated cells of E. coli, and of pigs inoculated with live S. cholerae-suis, showed that the glomerular "microthrombi" consisted predominantly of red cells and red cell debris (Figs. 7-9).

\section{DISCUSSION}

It became apparent from our studies that the necrotizing mural lesions with thrombotic complications, in cortical arteries play a decisive role in the pathogenesis of $\mathrm{BCN}$; they are actually a prerequisite for its development. This is contradictory to the current view on the pathogenetic mechanism of the renal 
Shwartzman damage, as this phenomenon is, at present attributed to disseminated intravascular coagulation by most authors (Thomas \& Good 1952, McKay 1965, Urizar et al. 1975), but in accordance with the older conception of the development of human BCN, in which such lesions were given considerable attention as a pathogenetic factor (Duff \& More 1941). After having given a comprehensive review of human cases of BCN, with detailed macroscopic and microscopic descriptions, Duff \& More state in their excellent paper: "This can only lead to the conclusion, which seems self-evident, that any mechanism capable of causing more or less simultaneous and prolonged interruption of bloodflow through a large number of the cortical arteries will produce the picture of symmetrical necrosis of the renal cortex". The same opinion was expressed some years earlier by Röhrer (1932), who was the first to describe BCN in domestic animals (pigs). According to this view, the BCN represents a massive infarction of the renal cortex, following the coalescence of numerous small infarcts. This is a concept which also seems "self-evident" to morbid anatomists, as renal infarcts, in general, develop after occlusions of arcuate or interlobular arteries. It seems peculiar that the changes in the renal arteries, which were so commonly included in somewhat older descriptions of human BCN, and experimentally induced GSR in rabbits (Stoeckenius 1921, Geipel 1925, Scriver \& Oertel 1930, Ash 1933, von Zalka 1933, De Navasguez 1935, Gáspár 1938, French 1940, Duff \& More, More \& Kobernick 1951), have only exceptionally been mentioned by other recent authors (Lambert et al. 1969) in connection with the experimental BCN, after this condition was associated with disseminated intravascular coagulation. It has been claimed that the terminal arteries in the renal cortex are extremely vulnerable to hypersensitive damage (Duff $\&$ More), and it seems that the necrotizing lesions in the walls of the cortical arteries are morphologically very similar to those described as hypersensitivity angiitis or allergic vasculitis (Zeek et al. 1948, Zeek 1952). Both endotoxin (Hoff et al. 1967, Gaynor et al. 1970, Stewart \& Anderson 1971, Gerrity et al. 1975) and Liquoid (Evensen \& Shepro 1973) damage vascular endothelium; heparinization does not protect against endotoxin-induced endothelial injury (Gaynor et al.), and the well documented protection of the renal Shwartzman reaction by anticoagulants (Good \& Thomas 1953, Shapiro \& McKay 1958) may, in our 
opinion, rather depend on the prevention of secondary thrombosis in arcuate and interlobular arteries, following endothelial lesions, than on disseminated intravascular coagulation, primarily provoked by the injected material. It has been suggested that transient adherence of platelet aggregates to the vascular lining may lead to mural lesions (Hughes \& Tonks 1962, J $\phi r-$ gensen et al. 1970); thus an early endothelial injury could be thought to start the development of the widespread arterial lesions, including occlusive complications, which occur in the terminal renal arteries in fulminant cases of BCN. It has also been demonstrated that vasomotor factors with vasodilatation, play an important pathogenetic role in the renal Shwartzman phenomenon (Gilbert 1960, Lambert et al., Collins et al. 1972), and it seems possible that the mural lesions may contribute to the excessive vasodilatation and circulatory collapse in renal vessels, even in the absence of thrombotic occlusions.

Older reports of human $\mathrm{BCN}$, or experimental $\mathrm{BCN}$ in animals, frequently contained descriptions of "conglutinated red cells", "conglutination thrombi", "deposit of damaged red cell corpuscles" or "stasis" in glomerular capillaries (Geipel, Scriver \& Oertel, De Navasguez, Gáspár, Duff \& More, More \& Kobernick), in contrast to recent papers, in which red cell thrombi in glomerular capillaries have rarely been described from other laboratories (Lambert et al.). Our investigations indicate that, although cortical necrotic lesions do not develop until the necrotizing mural arterial lesions are manifest, the primary event, observable in the light microscope, is stagnation of erythrocytes within the glomerular capillaries which are frequently excessively dilated; the stagnant red cells necrotize successively, to form hyaline masses which often stain as fibrin (Nordstoga 1974). The formation of hyaline "thrombi", representing erythrocytic debris, is a process which has long been recognized in association with the phenomenon known as true stasis (Kreyberg 1929, 1963). Erythrocytes contain large amounts of adenosine diphosphate, a substance which initiates platelet aggregation (Gaarder et al. 1961), and it seems possible that local release of adenosine diphosphate from stagnant, disintegrating red cells could accentuate platelet adherence to a damaged arterial lining.

The routine fibrin staining methods are by no means specific. Necrotic substances, of varying origin, may frequently show staining properties similar to fibrin in extravascular sites (Len- 
drum et al. 1962, Nordstoga 1974), and if it is accepted that necrotic material may also be present intravascularly, it is probable that such deposits, within vessel lumina, may also exhibit tinctorial characteristics akin to those of fibrin. It is evident from our electron microscopic investigation, in which porcine salmonellosis was used as an experimental model, that the bulk of the fibrinoid material was derived from disintegrating erythrocytes (Nordstoga 1974). Other workers have, however, shown that, under other experimental conditions, true fibrin may be incorporated in the "fibrin thrombi" in GSR (Bohle et al. 1957, Still \& Scott 1966). In our opinion, in seems clear that even apparently unchanged red cells constitute an essential component of the micro-circulatory "thrombi", since erythrocytes were often found trapped in the hyaline or fibrinoid material. After re-examination of sections from our previous experiments, based on several experimental models, we feel that this may be demonstrated even in light microscopic material. From this point of view, it seems, under any circumstance, and regardless of the origin of the fibrinoid material, inadequate to describe the occlusive deposits in the glomerular capillaries as pure "fibrin thrombi".

Leakage of fluid from minute vessels is considered to be an important event in the development of stasis (Kreyberg 1963); in the renal lesions of the GSR, this phenomenon can be thought to be caused by a disturbance in glomerular filtration, with an increased escape of fluid to the capsular space, followed by packing of red cells and cessation of blood flow in the glomerular capillaries. It seems that obstruction of glomerular circulation, induced in this way, is a necessary step in the elicitation of the renal damage, as it has been shown that the experimental BCN is prevented by repression of glomerular filtration (Watchi $\&$ Altman 1972).

As discussed above, the mutual interrelationship between glomerular stasis and the necrotizing and thrombotic lesions in the afferent arterial system remains obscure, but it is evident that the former precedes the latter.

To summarize, our investigations have shown that one can distinguish between at least 2 stages in the development of the experimental $\mathrm{BCN}$ :

In the first stage, observable in the light microscope, there is stagnation and disintegration of red cells in the glomerular 
capillaries, with formation of fibrinoid thrombi, but no obvious cortical alterations.

The second stage is characterized by necrotizing lesions in the walls of interlobular arteries and afferent glomerular capillaries, accompanied by thrombosis. If these vascular changes are diffusely distributed, complete BCN occurs; if the arterial lesions only occur in scattered areas, the kidney damage has the appearance of isolated infarcts. Total BCN occurs when the individual infarcts coalesce to form diffuse necrotic lesions in the cortical tissue.

\section{ACKNOWLEDGEMENT}

The author is indebted to Professor, Dr. med. H. Stormorken, for valuable discussions during the preparation of this paper.

\section{REFERENGES}

Ash, J. E.: Bilateral cortical necrosis of the kidneys (angioneurotic anuria). Amer. J. med. Sci. 1933, 185, 71-86.

Bohle, A., H. Sitte \& F. Miller: Elektronenmikroskopische Untersuchungen am Glomerulum des Kaninchens beim generalisierten Shwartzman-Phänomen. (Electron microscopic investigations of glomerulus of rabbits in the generalized Shwartzman phenomenon). Verh. dtsch. Ges. Path. 1957, 41, 326-332.

Collins, A. D., E. C. Henson, S. R. Izard \& J. G. Brunson: Norepinephrine, endotoxin shock, and the generalized Shwartzman reaction. Arch. Path. 1972, 93, 82-88.

De Navasguez, S.: The histology and pathogenesis of bilateral cortical necrosis of the kidney in pregnancy. J. Path. Bact. 1935, 41, $385-396$.

Duff, G. L. \& R. H. More: Bilateral cortical necrosis of the kidneys. Amer. J. med. Sci. 1941, 201, 428-450.

Evensen, S. A. \& D. Shepro: Generalized Shwartzman reaction induced by Liquoid in the rat. Increased DNA-synthesis in aortic endothelium. Thrombos. Diathes. haemorrh. (Stuttg.) 1973, 30, 347-351.

French, $R$. W.: Acute necrosis of the kidneys. Report of a case. Amer. J. Surg. 1940, 47, 666-669.

Friedländer, C.: Ueber Nephritis scarlatinosa. (On scarlatinal nephritis). Fortschr. Med. 1883, 1, 81-89.

Gaarder, A., J. Jonsen, S. Laland, A. Hellem \& P. A. Owren: Adenosine diphosphate in red cells as a factor in the adhesiveness of human blood platelets. Nature (Lond.) $1961,192,531-532$.

Gáspár, I. A.: Bilateral cortical necrosis of the kidneys. Amer. J. clin. Path. 1938, 8, 281-301.

Gaynor, E., C. Bouvier \& T. H. Spaet: Vascular lesions: Possible pathogenetic basis of the generalized Shwartzman reaction. Science $1970,170,986-988$. 
THE SEQUENCE OF EVENTS

IN THE DEVELOPMENT OF BILATERAL

RENAL CORTICAL NECROSIS ACCOMPANYING

THE GENERALIZED SHWARTZMAN REACTION

By

Knut Nordstoga 



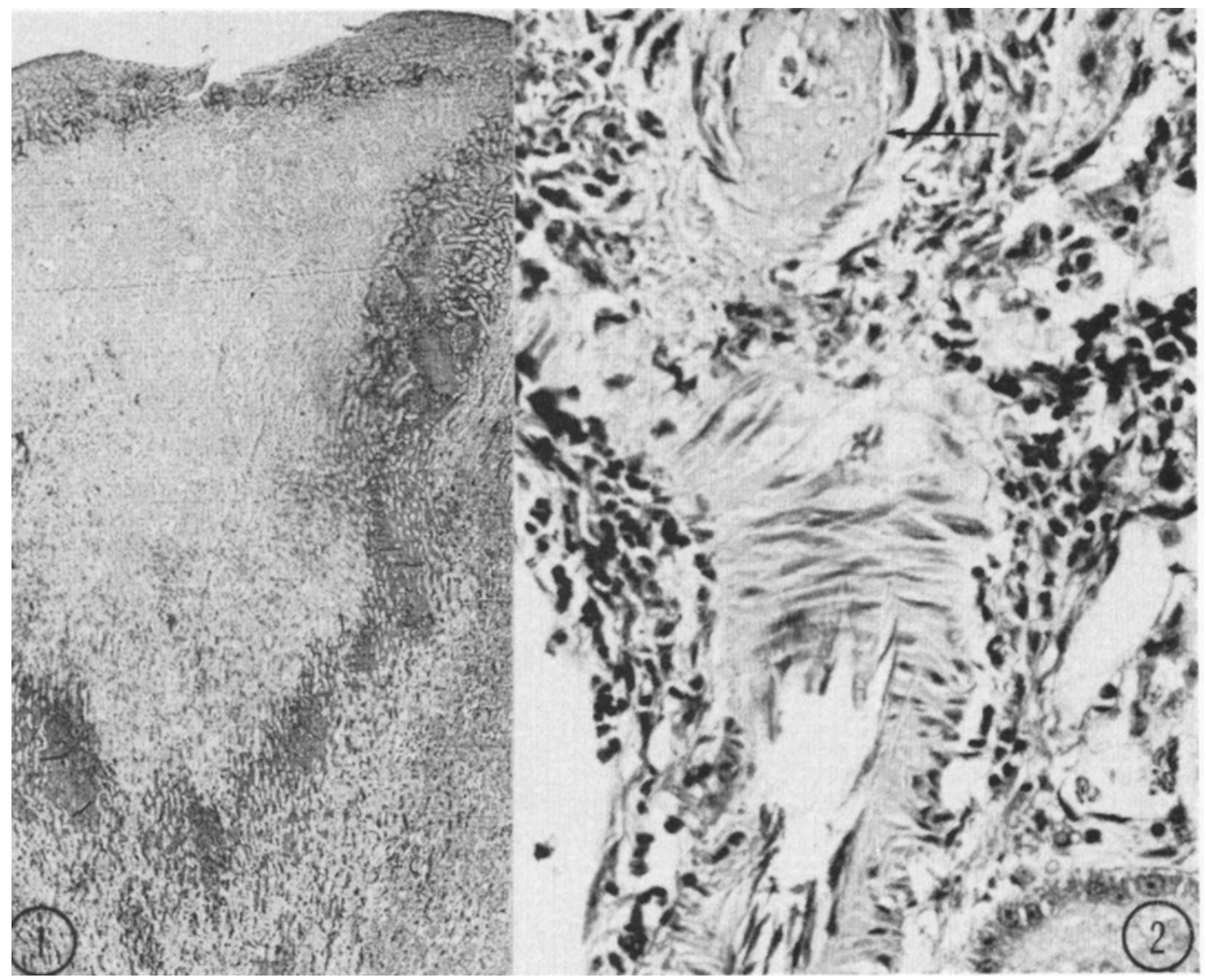

Figure 1. A renal infarct in a ferret injected twice intracardially with disintegrated cells of Escherichia coli. H \& E, $\times 17$.

Figure 2. A thrombosed interlobular artery in a ferret injected twice intracardially with crushed cells of Escherichia coli. The thrombotic lesion is indicated by an arrow; there is perivascular accumulation of mononuclear inflammatory cells around an arcuate artery with unchanged wall. $\mathrm{H} \& \mathrm{E}, \times 425$. 


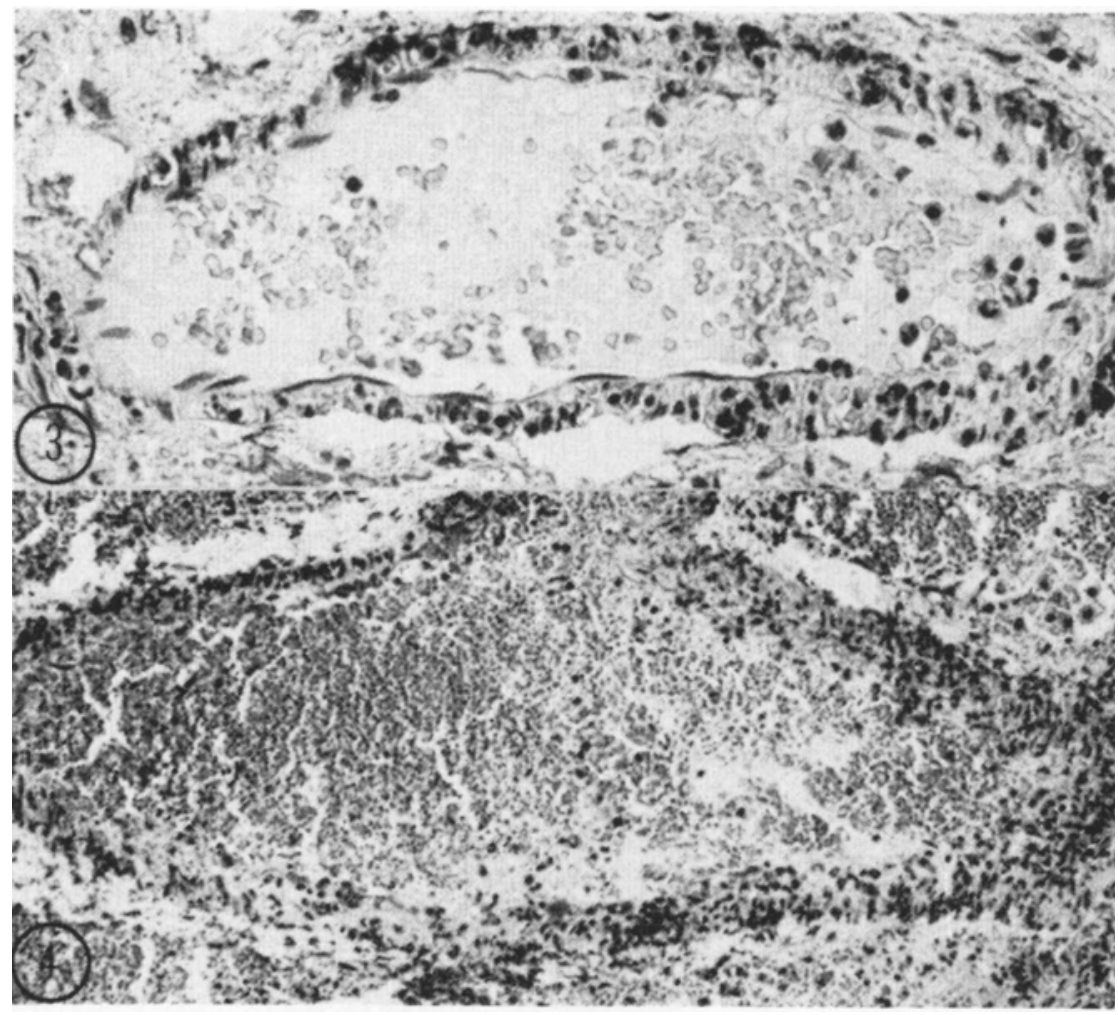

F i g u r e 3. Necrotizing lesion in an interlobular artery of a rabbit injected intravenously with Liquoid. There is incipient thrombosis, and slight infiltration of mononuclear cells and eosinophils in the necrotic wall. $\mathrm{H} \& \mathrm{E}, \times 425$.

$\mathrm{F}$ i g u r e 4. Necrotizing changes in the wall of an interlobular artery of a pig injected twice with disintegrating cells of Haemophilus parainfluenzae. There is pronounced infiltration of inflammatory cells in the necrotic wall. $\mathrm{H} \& \mathrm{E}, \times 170$. 


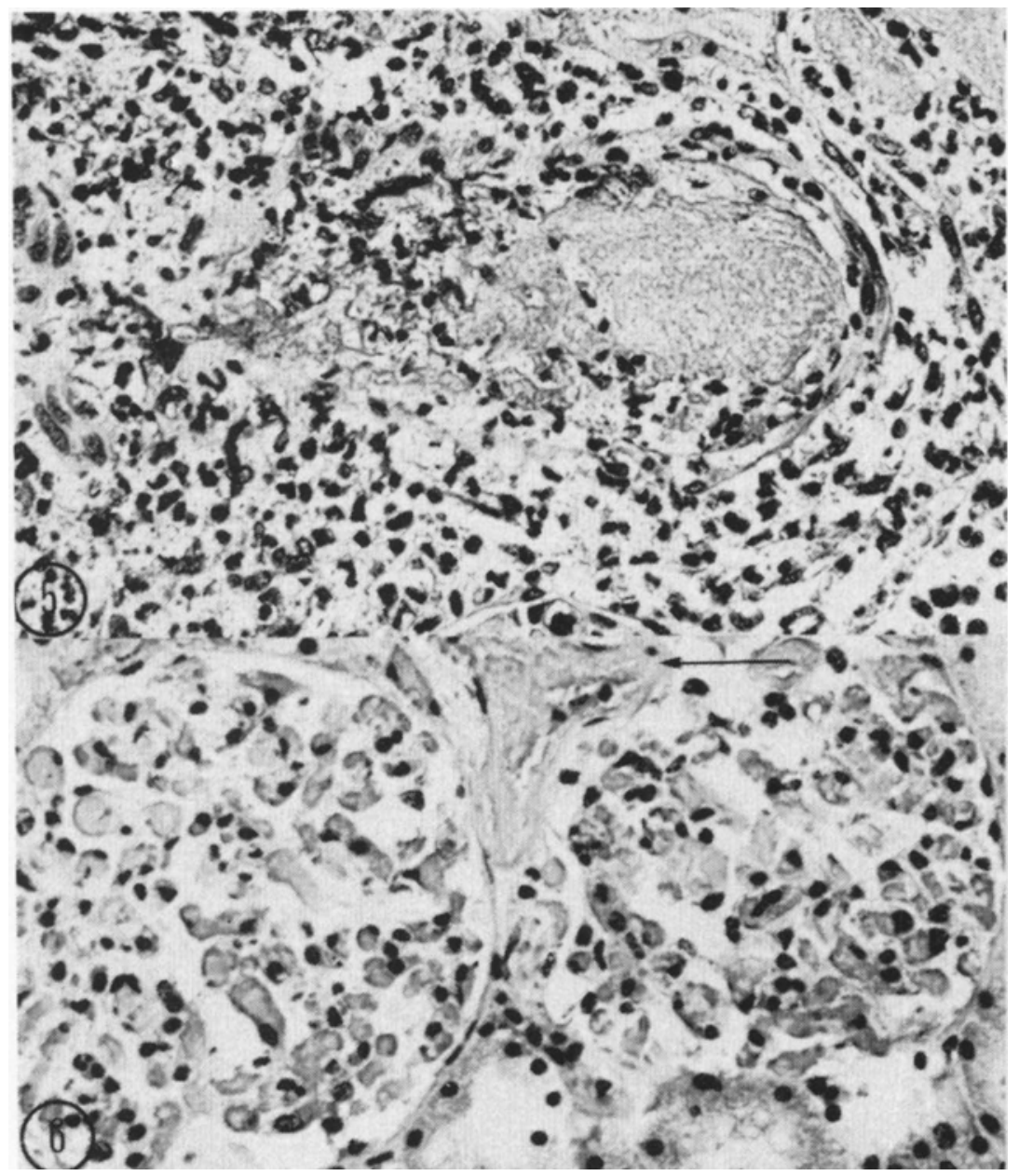

Figure 5. A thrombosed interlobular artery of a mink which was injected twice intracardially with disintegrated cells of Escherichia coli. There is heavy infiltration of inflammatory cells around the partly destroyed vessel. $\mathrm{H} \& \mathrm{E}, \times 425$.

Figure 6. Glomerular "thrombosis" in a blue fox injected intravenously with Liquoid. There are incipient necrotic lesions in an afferent glomerular arteriole (arrow). There were no gross lesions in the kidneys of this animal, except for somewhat mottled external surfaces. $\mathrm{H} \& \mathrm{E}, \times 425$. 


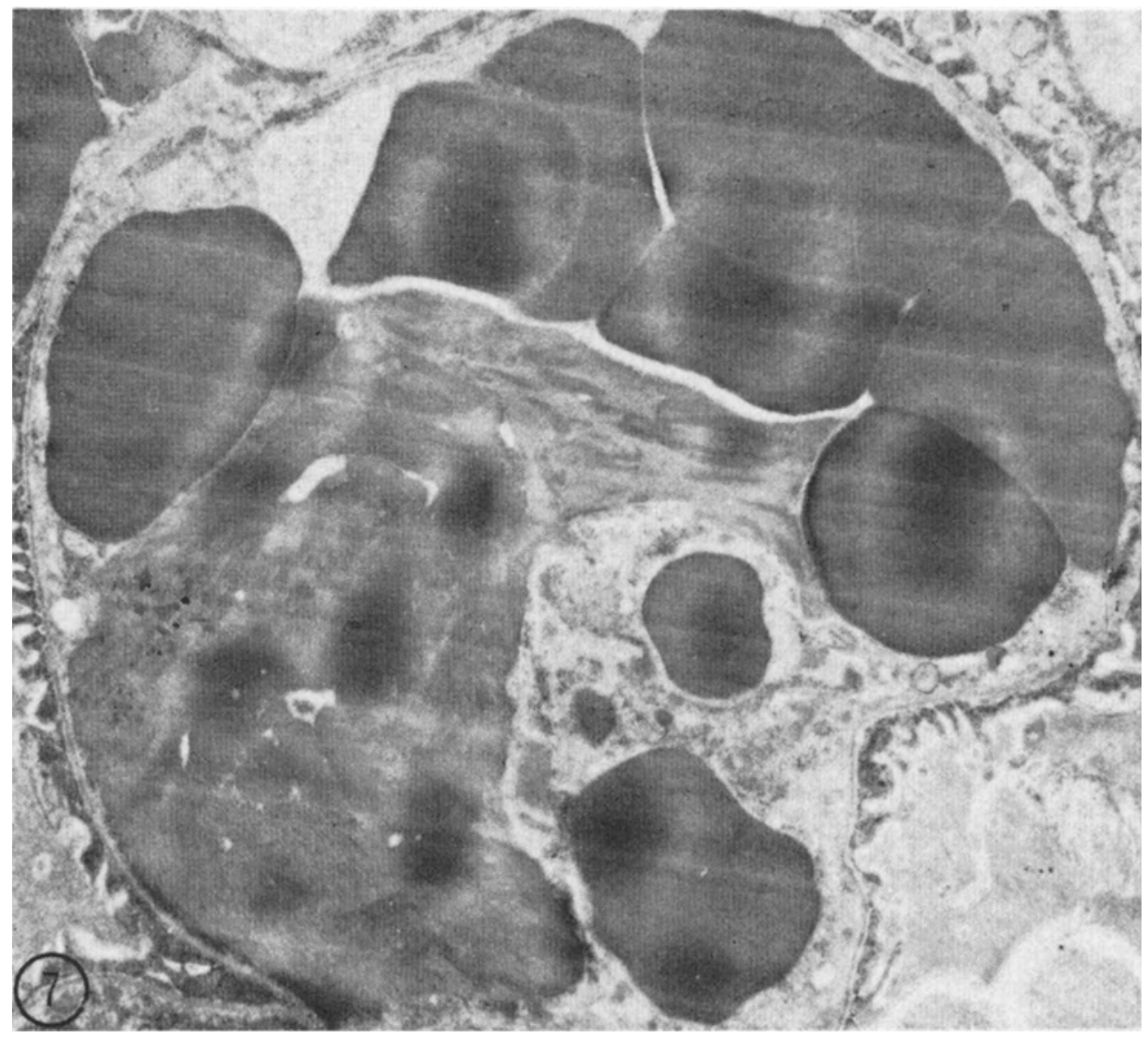

Fig u r e 7. A "thrombus", consisting of erythrocytes and erythrocytic debris, occludes a distended glomerular capillary. Septicaemic salmonellosis, pig. $\times 800.0$.

Fig u r e 8. A dilated glomerular capillary occluded by red cells and a mass with somewhat varying electron density. Septicaemic salmonellosis, pig. $\times 12000$.

Figure 9. Higher magnification of the framed part of Fig. 8 . Erythrocytic membranes are visible in some parts of the figure. The mass in the lower left of the picture has an ultrastructure which is very similar to that of the erythrocytes. $\times 60000$. 


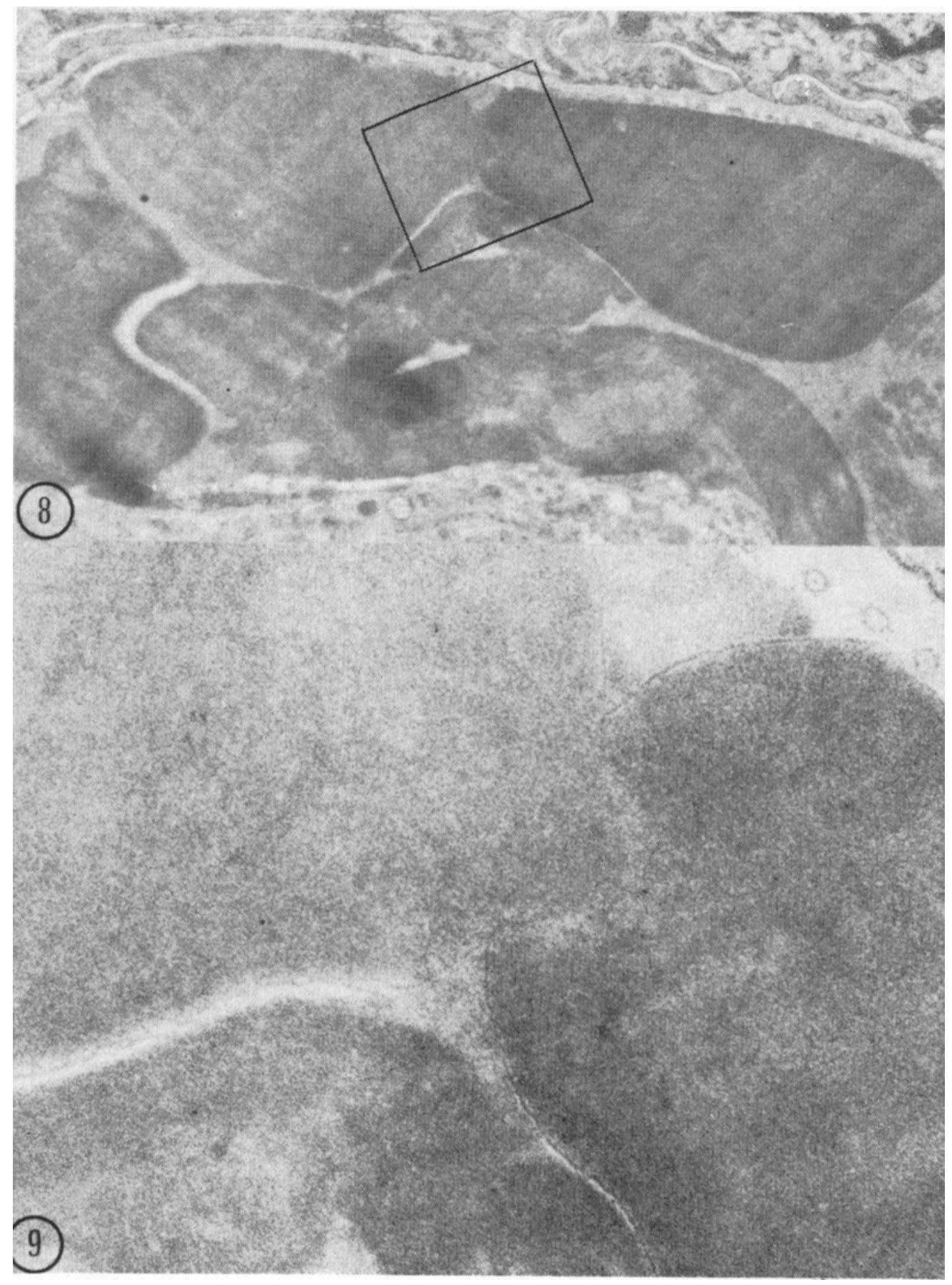



Geipel, P.: Nierenrindennekrose und Fleckmilz bei Eklampsie. (Renal cortical necrosis and spotted spleen in eclampsia). Arch. Gynäk. 1925, 124, 231-240.

Gerrity, R. G., B. A. Caplan, M. Richardson, J. F. Cade, J. Hirsh \& C. J. Schwartz: Endotoxin-induced endothelial injury and repair. I. Endothelial cell turnover in the aorta of the rabbit. Exp. Molec. Path. 1975, 23, 379-385.

Gilbert, R. P.: Mechanisms of the hemodynamic effects of endotoxin. Physiol. Rev. 1960, 40, 245-279.

Good, R. A. \& L. Thomas: Studies on the generalized Shwartzman reaction. IV. Prevention of the local and generalized Shwartzman reaction with heparin. J. exp. Med. 1953, 97, 871-888.

Hoff, H. F., R. Gottlob \& G. Blümel: Ultrastructural changes in arteries induced by endotoxin. Naturwissenschaften 1967, 54, 287-288.

Hughes, A. \& R. S. Tonks: Intravascular platelet clumping in rabbits. J. Path. Bact. 1962, 84, 379-390.

Jørgensen, L., T. Hovig, H. C. Rowsell \& J. F. Mustard: Adenosine diphosphate-induced platelet aggregation and vascular injury in swine and rabbits. Amer. J. Path. 1970, 61, 161-176.

Kreyberg, L.: Über präcanceröse Gefässveränderungen. (On precancerous vascular changes). Virchows Arch. path. Anat. 1929, 273, $367-440$.

Kreyberg, L.: Stasis and Necrosis. Universitetsforlaget, Oslo 1963.

Lambert, P. B., S.-C. Ming \& C. Palmerio: Vasomotor factors in the Shwartzman phenomenon. Amer. J. Path. 1969, 57, 559-580.

Lendrum, A. C., D. S. Fraser, W. Slidders \& R. Henderson: Studies on the character and staining of fibrin. J. clin. Path. 1962, 15, $401-413$.

McKay, D. G.: Disseminated Intravascular Coagulation. An Intermediary Mechanism of Disease. Hoeber Medical Division, New York 1965.

More, R. H. \& S. D. Kobernick: Arteritis, carditis and glomerulonephritis and bilateral renal cortical necrosis induced in rabbits, by injection of horse serum or bovine gamma globulin combined with killed group A streptococci or Freund's adjuvant. Arch. Path. 1951, 51, 361-378.

Nordstoga, $K .:$ Porcine salmonellosis: A counterpart to the generalized Shwartzman reaction. Origin of hyaline material precipitated in minute vessels. Acta path. microbiol. scand. Sect. A 1974, 82, $690-702$.

Nordstoga, K.: Liquoid-induced arterial lesions and the generalized Shwartzman reaction. Acta vet. scand. 1977, 18, 515-521.

Nordstoga, K. \& M. Fjølstad: The generalized Shwartzman reaction and Haemophilus infections in pigs. Path. Vet. 1967, 4, 245-253.

Nordstoga, K. \& M. Fjølstad: Porcine salmonellosis. II. Production of the generalized Shwartzman reaction by intravenous injections of disintegrated cells of Salmonella cholerae-suis. Acta vet. scand. $1970,11,370-379$. 
Nordstoga, K.\& M. Fjølstad: Necrotizing angiitis produced by the Shwartzman mechanism. Acta path. microbiol. scand. Sect. A, $1973,81,775-783$.

Nordstoga, K. \& M. Fjфlstad: Pulmonary vascular lesions in chickens following intravenous injections of disintegrated cells of Escherichia coli. Acta path. microbiol. scand. Sect. A, 1975, 83, 283291.

Röhrer, H.: Pathologisch-anatomische und histologische Studien bei akuter Schweinepest, insbesondere an Leber und Niere. Mit einem Anhang über totale Nierenrindennekrosen. (Pathologicanatomic and histologic studies on acute swine fever, with special reference to liver and kidney. With an addendum on total renal cortical necroses). Virchows Arch. path. Anat. 1932, $284,203-230$.

Scriver, W. de M. \& H. Oertel: Necrotic sequestration of the kidneys in pregnancy (symmetrical cortical necrosis). A clinical and anatomic-pathogenetic study. J. Path. Bact. 1930, 33, 10711094.

Shapiro, S. S. \& D. G. McKay: The prevention of the generalized Shwartzman reaction with sodium warfarin. J. exp. Med. 1958, 107, 377-381.

Stewart, G. J.\& M. J. Anderson: An ultrastructural study of endotoxin induced damage in rabbit mesenteric arteries. Brit. J. exp. Path. 1971, 52, 75-80.

Still, W. J. S. \& G. B. D. Scott: An electron microscopic study of the endothelial changes and the nature of "fibrinoid" produced in the generalized Shwartzman reaction. Exp. Molec. Path. 1966, 5, 118-124.

Stoeckenius, W.: Ưber fast vollständige doppelseitige Nierenrindennekrose bei Diphtherie. (On almost complete bilateral renal cortical necrosis in diphtheria). Beitr. path. Anat. 1921, 69, $373-379$.

Thomas, L. \& R. A. Good: Studies on the generalized Shwartzman reaction. I. General observations concerning the phenomenon. J. exp. Med. 1952, 96, 605-624.

Urizar, R. E., G. Sherer, A. Tartaglia, R. J. Pickering \& W. J. Dodds: Disseminated intravascular coagulation induced by Liquoid in the rat. I. Correlation of hematologic and complement abnormalities with renal lesions studied by light, fluorescence, and electron microscopy. Lab. Invest. 1975, 32, 270_278.

von Zalka, E.: UUber symmetrische Rindennekrose der Niere. (On symmetrical renal cortical necrosis). Virchows Arch. path. Anat. 1933, 290, 53-70.

Watchi, J.M.\& J. Altman: Role of ureteric pressure in protecting the kidney against cortical necrosis during the Sanarelli-Shwartzman reaction: An argument in favour of the primary role of vascular spasm in the mechanism of cortical necrosis. Rev. europ. Étud. Clin. biol. 1972, 17, 982-987. 
Zeek, P. M.: Periarteritis nodosa: A critical review. Amer. J. clin. Path. 1952, 22, 777-790.

Zeek, P. M., C. C. Smith \& J. C. Weeter: Studies on periarteritis nodosa. III. The differentiation between the vascular lesions of periarteritis nodosa and of hypersensitivity. Amer. J. Path. 1948, 24, $889-917$.

\section{SAMMENDRAG}

Rekkefølgen $i$ utviklingen av de patologisk-anatomiske forandringer ved dobbeltsidig nyrebarknekrose og den generaliserte Shwartzman's reaksjon.

Generalisert Shwartzman's reaksjon, eller Shwartzman's lignende tilstander, ble framkalt hos en rekke arter av pattedyr ved injeksjon av disintegrerte Gram negative bakterier, levende Salmonella choleraesuis, eller Liquoid. En komparativ studie av nyreskaden viste at de f $\varnothing$ rst registrerbare forandringer $i$ glomeruli er stase og disintegrering av røde blodlegemer i kapillærene i glomeruli. "Mikrotrombene“ i glomeruli består vesentlig av henfallende erytrocytter; dette materialet har ofte samme fargeegenskaper som fibrin. Selv uttalte „tromboseringer" $i$ glomeruli er ikke ledsaget av tydelige makroskopiske henfallsprosesser i nyreparenchymet. Et neste skritt er utvikling av nekrotiserende forandringer $i$ veggen av afferente arterier; disse karveggsforandringene er ofte ledsaget av tromboseringer. Karforandringene fører til dannelse av infarkter som så flyter sammen og gir total nyrebarknekrose i fulminante tilfeller av den generaliserte Shwartzman's reaksjon.

(Received July 13, 1977).

Reprints may be requested from: K. Nordstoga, the Department of Pathology, Veterinary College of Norway, P.O. Box 8146, Oslo Dep., Oslo 1, Norway. 